\title{
Retinoic Acid Receptor RXR-Beta
}

National Cancer Institute

\section{Source}

National Cancer Institute. Retinoic Acid Receptor RXR-Beta. NCI Thesaurus. Code C38418.

Retinoic acid receptor RXR-beta (533 aa, $27 \mathrm{kDa}$ ) is encoded by the human RXRB gene. This protein plays a role in both transcriptional regulation and 9-cis retinoic acid binding. 